\title{
NIHILISME DALAM FILM A CLOCKWORK ORANGE KARYA STANLEY KUBRICK (Kajian Semiotika Sastra)
}

\author{
Bayu Ade Prabowo \\ Magister Ilmu Susastra, Universitas Diponegoro \\ Jalan Imam Bardjo Nomor 5, Pleburan, Semarang 50241 \\ Email: bayuadeprabowo@gmail.com
}

\begin{abstract}
This study with the title Nihilism in the Stanley Kubrick's film A Clockwork Orange aims to reveal the meaning of the signs in the film. The source of the study is A Clockwork Orange film which directed by Stanley Kubrick. This study use semiotics approach and this study focuses on the signs in the movie which relate to nihilism. The result of this study is revealing the music Symphony No. $9^{\text {th }}$ by Ludwig van Beethoven as the primary signifier. These music relate to the nihilism as the character of Alex DeLarge. This study also reveal the signs that relate to the nihilism and it also reveal that A Clockwork Orange movie as an illustration of nihilism that happened in the England in 1960s.
\end{abstract}

Keyword: semiotics, Symphony No. 9, A Clockwork Orange.

\section{Pendahuluan}

Film sama halnya dengan karya sastra yang lainnya, merupakan sebuah gambaran fiksi yang dikemas oleh sutradara, kameramen, penata busana, penata latar, komposer dan penata letak adegan dari kenyataan yang ada. Apa yang ada di film adalah sebuah rekaan imajinasi dari seorang sutradara. Rekaan ini merupakan alih wahana dari naskah yang ditulis oleh penulis naskah maupun dari sutradara itu sendiri. Untuk mendapatkan rekaan ini, sutradara bisa mendapatkannya dari apa yang sang sutradara temui dalam kehidupannya.

Sutradara sama halnya dengan pengarang juga memiliki komunikasi tersendiri dengan penonton. Komunikasi ini bisa terbentuk jika penonton tidak menganggap film sebagai media hiburan saja. Menurut Ehrat (2005:15) jika film diperlakukan dengan perspektif normal saja, maka poin-poin yang menjadi pandangan sang pembuat film menjadi hilang. Hal itu akan ditunjang dengan referensial penonton yang begitu luas. 
Film A Clockwork Orange (seterusnya menjadi ACO) mengangkat masalah kekerasan-kekerasan yang terjadi dikalangan pemuda di Inggris. Tidak hanya itu, film ini juga memperlihatkan sindiran terhadap sistem politik yang mampu mengagendakan sesuatu (dalam hal ini adalah tindak kekerasan yang dilakukan oleh para pemuda Inggris) menjadi sebuah agenda politik untuk melanggengkan jabatannya.

\section{Film A Clockwork Orange} menceritakan tentang seorang pemuda berumur 17 tahun bernama Alex DeLarge. Alex memiliki geng yang teman-temannya biasa ia panggil droogs. Mereka setiap malam melakukan perampokan, berkelahi dengan geng yang lain, memukuli tunawisma hingga melakukan pemerkosaan. Masalah muncul ketika teman-temannya mulai tidak suka dengan gaya Alex yang terlalu otoriter hingga akhirnya Alex dijebak dan ditangkap oleh polisi atas tuduhan pembunuhan. Di penjara, Alex berusaha mencari cara untuk segera keluar dari penjara dengan cara mengikuti terapi yang diciptakan oleh pemerintah dalam rangka mengurangi tingkat kekerasan dengan cara menghilangkan hasrat untuk melakukan kekerasan.

Dari ringkasan singkat tentang isi film tersebut, ACO merupakan sebuah film yang memiliki kaitan erat dengan nihilisme dan kaitannya dengan apa yang terjadi di Inggris era tahun 60an seperti yang disinggung diatas. Sehingga dengan meneliti film ACO diharapkan akan ditemukan tanda-tanda yang menunjukkan adanya nihilisme sebagai masalah yang ada pada penilitian ini.

Semiotika menurut Cobley dan Jansz (1999) berasal dari bahasa Yunani, kata seme dalam semiotikos mengarah pada pengertian interpretasi terhadap tanda. Jadi Semiotik sendiri merupakan disiplin ilmu yang menganalisis tanda atau studi mengenai fungsi-fungsi sistem tanda. Menurut Chandler (2007:2) semiotika merupakan ilmu yang tidak hanya mengarah kepada 'tanda' dalam komunikasi sehari-hari, melainkan apapun yang 'mengacu' pada suatu hal lainnya.

Dalam pernyataan di atas, Chandler menganggap bahwa semiotika sekarang ini sudah tidak lagi berkutat kepada komunikasi saja, tetapi apapun itu yang memiliki sesuatu yang mengacu pada suatu 
hal lainnya termasuk dalam ranah pendekatan semiotika.

Semiotika dikembangkan oleh dua tokoh yang bernama Ferdinand de Saussure dan Charles Sanders Peirce. Saussure dalam bukunya Course in General Linguistics menyatakan bahwa "Semiology would show what constitutes signs, what laws govern them." (dalam Stam, 1999:4). Dalam memahami tanda, Saussure menyebutnya semiologi.

Dalam semiologi tersebut, Saussure melihat bagaimana cara memperlakukan tanda dan bagaimana pada akhirnya Saussure menciptakan teori untuk memahaminya. Dalam hal ini Sausussure dengan semiologinya melihat bahwa dalam sebuah tanda terdapat signifier atau penanda dan signified atau petanda. Signifier merupakan wujud dari materi tanda tersebut dan signified merupakan konsep yang diwakili penanda tadi (Wardoyo, 2005:2).
Skema 1: Proses signifikasi



Konsep-konsep Saussure (dalam Ratna, 2015:99) adalah sebagai berikut ini: Terdiri atas pasangan yang beroposisi, tanda-tanda yang memiliki dua sisi, sebagai dikotomi, seperti: penanda (signifier, signifiant, semaion) dan petanda (signified, signifie, semainomenon), ucapan individual (parole) dan bahasa umum (langue), sintagmatis dan paradigmatis, dan diakroni dan sinkroni.

Peirce memberikan pendekatan yang berbeda dari Saussure terhadap tanda. Tanda sendiri didefinisikan oleh Peirce bahwa "sign as something which stands to somebody for something in some respect or capacity." (dalam Stam, 1999:5). Pemahaman terhadap pernyataan dari Peirce adalah bahwa pemaknaan tanda akan tampak oleh seseorang jika orang tersebut memiliki kapasitas konsep terhadap benda yang dilihatnya. 
Ratna (2015:101) menyebutkan bahwa konsep Peirce ditandai oleh dinamisme internal dalam triadiknya Peirce. Dalam hal ini terdapat tiga konsep utama; sintaksis semiotika (hubungan tanda dengan tanda yang lain), semantik semiotika (hubungan tanda dengan acuannya) dan pragmatik semiotik (hubungan antara pengirim dan penerima tanda).

Melihat uraian diatas, Peirce melakukan uraian yang mendalam antara hubungan-hubungan antara tanda, acuan dan komunikasi tanda untuk menemukan adanya pemaknaan tanda. Meski tidak semuanya dilakukan untuk hanyua untuk mengolah tanda-tanda.

Lebih jauh Peirce menjelaskan tentang adanya tiga unsur dalam tanda; representamen, objek dan interpretan. Representamen adalah unsur tanda yang mewakili sesuatu, objek adalah sesuatu yang diwakili, dan interpretan adalah tanda yang tertera di dalam pikiran si penerima setelah melihat representamen (Zaimar, 2014:3).

Selain menjelaskan tentang unsur dalam tanda, Peirce juga menyebutkan tentang jenis-jenis tanda sebagaimana yang dikutip oleh Stam (1999:5) yaitu iconic sign, indexical sign dan symbolic sign. Iconic sign atau icon merupakan tanda yang serupa dengan yang ditandai, indexical sign atau indeks merupakan tanda yang bersifat terkait otomatis dalam suatu hal dengan yang ditandai, dan symbolic sign atau simbol merupakan tanda yang tidak serupa dengan yang ditandai tapi arbitrer dan murni konvensional (Wardoyo, 2005:3).

Berkaitan dengan nihilisme, Brink (1989: 14) menyatakan bahwa moral realism is a kind of metaphysical thesis about nature and status of moral claims. Dalam realisme moral maka terlihat bagaimana status moral dalam kehidupan, orang-orang akan tahu mana moral yang benar dan mana moral yang salah sesuai dengan lingkungan mereka hidup. Hanya saja bagaimana menentukan mana yang benar dan salah itu lah yang menjadi objek penelitian.

Brink dalam hal ini mencoba untuk memformulasikan realisme moral sebagai berikut ini:

MR: (1) there are moral facts or truths, and (2) these facts or truths are indipendent of the 
evidence for them. (Brink, 1989:17)

Nihilisme moral sendiri memang muncul dari adanya skeptisisme moral. Hal itu juga dinyatakan oleh Mackie (1977: 18) it is because they have assumed that there are no objective values that they have looked elsewhere for an analysis of what moral statements might mean. Karena mereka merasa tidak ada objektivitas dalam nilai-nilai yang mereka cari, mereka merasa apa yang mereka lakukan apa yang mereka pikirkan adalah benar. Dalam pembenaran ini pulalah muncul sikap nihilisme moral.

Nihilisme dari bahasa latin yang berarti 'nihil' atau kosong. Nihilisme banyak digunakan pada beberapa mahzab filsafat. Bahwa dalam nihilisme sesuatu itu tidak ada sama sekali, apa yang kita tahu itu tidak ada. Tidak ada prinsip moral. Semua hal yang tidak konkrit adalah nihil atau kosong.

\section{Metode Penelitian}

Objek material dalam penelitian ini adalah film A Clockwork Orange karya Stanley Kubrick. Sementara yang menjadi objek formal dalam penelitian ini adalah semiotika sastra. Penelitian ini menggunakan semiotika sastra untuk membedah tanda-tanda dalam film sehingga ditemukan penanda utama. Serta untuk menentukan tanda-tanda yang berkaitan dengan nihilisme.

Penelitian ini termasuk kedalam penelitian kepustakaan sehingga tandatanda yang ada berupa cuplikan gambar adegan dan dialog yang ada di dalam objek material saja, yaitu film ACO. Metode pengumpulan data dalam penelitian ini adalah studi kepustakaan, yaitu mengumpulkan data primer dan sekunder.

Data primer diperoleh dari objek materialnya, sedangkan data sekunder diperoleh dari sumber kepustakaan lain yang terkait dengan objek penelitian. Setelah data-data tersebut terkumpul, yaitu berupa tanda-tanda, kemudian dianalisis dengan menggunakan pendekatan semiotika dan ditunjang dengan teori nihilisme untuk memperkuat pemaknaannya.

\section{Hasil dan Pembahasan}

Lagu Symphony No. 9 menjadi penanda utama dalam film ACO karena lagu ini memiliki peran penting dalam cerita. Symphony No. 9 diperlihatkan di dalam film seperti halnya apa yang diperlihatkan oleh Alex DeLarge. Alex DeLarge seakan- 
akan perlambangan dari Symphony No. 9 tersebut.

Penelitian ini akan menjabarkan analisis Symphony No. 9 sebagai penanda utama dibagi menjadi dua yaitu Symphony No. 9 sebagai simbol kebebasan Alex sekaligus sebagai indeks kepribadian Alex.

Symphony No. 9 diperlihatkan di dalam film seperti halnya apa yang diperlihatkan oleh Alex DeLarge. Alex DeLarge seakan-akan perlambangan dari Symphony No. 9 tersebut. Peneliti akan menjabarkan analisis Symphony No. 9 sebagai penanda utama dibagi menjadi dua yaitu Symphony No. 9 sebagai simbol kebebasan Alex sekaligus sebagai indeks kepribadian Alex.

Penggunaan lagu ini dalam film tidak hanya sebagai scoring belaka, tapi lagu tersebut justru digunakan sebagai alat untuk menggerakkan plot. Symphony No. 9 digunakan juga sebagai penggambaran karakter Alex. Alex sebagai orang yang bebas, bebas dalam berlaku apapun yang sekiranya itu merupakan yang Alex senangi.

Setelah Alex melakukan rutinitas malamnya, Ia kembali ke kedai susu Korova. Di saat itulah Alex melihat seorang perempuan yang menyanyikan lagu Symphony No. 9. Alex merasakan adanya ketenangan batin ketika mendengarkan perempuan itu bernyanyi. Ia menarasikan perasaannya ketika mendengarkan lagu tersebut seperti pada kutipan dialog berikut ini:

ALEX: And it was, like, for a moment, my brothers, some great bird had flown into the milk bar. And it felt all the malenky little hairs on my plott standing endwise. And the shivers crawling up like slow, malenky lizards and then down again. Because I knew what she sangs. It was a bit from the glorious '9th' by Ludwig Van.

(ACO, 00:14:39,837 - 00:15:04,152)

Dari narasi tersebut bisa terlihat bagaimana simbol dari lagu Symphony No. 9 sebagai simbol atas kebebasan jiwa dan pikiran. Ia merasakan kebebasan dalam dirinya ketika mendengarkan lagu itu.

Perumpamaan yang digunakan Alex ketika menggambarkan perasaannya saat mendengar lagu tersebut seperti pada kalimat 'some great bird had flown into the milk bar and it felt all the malenky little hairs on my plott standing endwise'.

Sehingga dari hal tersebut bisa dilihat bagaimana narasi Alex disimbolkan dalam kebebasan karena dalam adegan 
tersebut Alex menggunakan bahasa kiasan dari 'burung' hingga 'kadal kecil' untuk menggambarkan kebebasan tersebut. 'Burung' selalu disimbolkan tentang kebebasan karena burung bisa terbang dan menjelajah di langit.

Ketika Alex mengatakan perumpaan tersebut adegan menggunakan kamera close up sehingga bisa diperlihatkan bagaimana ekspresi muka Alex. Peneliti menangkap bahwa untuk menampilkan kebebasan tersebut, Kubrick memadukan adegan close up yang dipadukan dengan offscreen voice dari perempuan tersebut. Hal ini untuk mempertegas kepada penonton bahwa inilah kenikmatan dan kebahagian Alex ketika mendengarkan lagu.

Hal ini merujuk kepada fenomena yang terjadi di Inggris di era 60 hingga 70an yang dikenal dengan era budaya tandingan. Para remaja mengekspresikan gairah mereka terhadap gaya berpakaian, musik dan lain sebagainya.

Alex sebagai perwakilan remaja di tahun 60an, menyukai musik klasik dan berpakaian yang menunjukkan kekontrasan di jamannya. Alex dengan berpakaian putih juga teman-temannya dan beberapa pengunjung di Kedai Susu Korova, mengindikasikan Alex mengikuti suatu kelompok. Hal ini merujuk pada pergerakan kelompok remaja di Inggris pada tahun 1960an yang terkenal dengan Mods dan Rockers. Di adegan ini pula diperlihatkan bagaimana Alex ditunjukkan sebagai nihilis aktif.

Nihilis aktif disini digambarkan ketika Alex merasa bersemangat, bahagia dan bebas. Hingga ia akan melakukan apapun.

Lagu Symphony No. 9 tampak kembali ketika Alex pulang ke rumahnya. Penampakan itu muncul di menit 18:26. Penampakan lagu ini memberi dua lambang yaitu sebagai simbol dan sebagai indeks.

Simbol kebebasan itu tampak dari montage dari fantasi ketika Alex mendengarkan lagu tersebut. Indeks muncul ketika Alex menarasikan bagaimana dia ketika mendengarkan lagu Symphony No. 9 seperti pada kutipan dialog berikut ini.

ALEX: Oh, bliss! Bliss and heaven! It was gorgeousness and gorgeosity made flesh. It was like a bird of rarest spun heaven metal. Or like silvery wine flowing in a spaceship gravity all nonsense now. As I 
slooshied I knew such a lovely pictures.

(ACO, 00:19:25,581 - 00:19:51,564)

Indeks tersebut terlihat dari narasi Alex yang jika dilihat secara heuristik hanyalah sekumpulan bahasa kiasan. Dari dikaitkan dengan burung hingga pesawat luar angkasa. Sedangkan secara hermeneutik menandakan bahwa Alex sangat bahagia karena lagu tersebut hingga ia mampu berfantasi sebegitu hebatnya.

Seperti yang diungkap sebelumnya dalam pembahasan Symphony No. 9 pertama bahwa lagu tersebut memiliki muatan lambang. Ketika lagu ini diputar pertama kali, sebuah foto Ludwig van Beethoven dipajang di kamar Alex tibatiba terjadi transisi kamera yang menjadi extreme close-up.

Hal ini bisa dijelaskan bahwa adanya penekanan dari Kubrick dalam menyampaikan adegan tersebut bahwa Alex begitu memuja Beethoven. Pemujaan ini akan memiliki pembahasan lebih di pembahasan lagu Symphony No. 9 berikutnya.

Setelah itu adegan berpindah ke tracking shot yang menunjukkan lukisan perempuan telanjang. Ketika kamera mengarah ke bawah, kamera memperlihatkan ular yang dalam tangkapan kamera menutupi alat kelamin perempuan di lukisan tersebut.

Peneliti menemukan adanya dua pesan yang ingin disampaikan oleh Kubrick dalam adegan tersebut. Pertama, Kubrick seakan ingin menunjukkan pandangan agama dia melalui adegan tersebut, kedua Kubrick ingin menegaskan karakteristik Alex sebagai seorang nihilist dari adegan tersebut.

Lalu kamera kembali mengarah ke bawah dan diperlihatkan patung menyerupai Yesus yang tidak diperlihatkan seperti biasanya. Patung tersebut diperlihatkan menyerupai empat Yesus dan mereka saling berangkulan, dengan tangan mengepal ke atas. Montage patung tersebut seperti mengisyaratkan bahwa mereka tengah melakukan unjuk rasa.

Pandangan Kubrick tentang agama kembali dipertegas dengan adanya patung tersebut. Terutama dengan serangkaian gambar dengan transisi yang cepat hingga menimbulkan efek seakan-akan mereka melakukan protes terhadap sesuatu.

$$
\text { Selain sebagai pesan yang }
$$
mengisyaratkan pandangan Kubrick 
tentang agama, karakteristik Alex sebagai seorang Nihilistik pun kembali dipertegas. Alex memang tidak digambarkan secara pasti apakah ia memang orang yang religius atau tidak, tapi hal itu justru memberi penekanan bahwa

Alex tidak sepenuhnya menganggap agama adalah hal penting bagi dia. Sehingga ia memperlakukan wanita seperti dalam lukisan tersebut, hanya sebagai objek pemuas belaka dan juga bagaimana ia memperlakukan junjungan tinggi agamanya seperti itu.

Peneliti menemukan bahwa selain memperlihatkan seperti apa pandangan Kubrick dalam agama, peneliti menemukan adanya relasi dengan kehidupan di masa 60an hingga 70an. Di rentang waktu itu tengah mewabahnya lagu-lagu beraliran psychedelic. Di selasela mewabahnya psychedelic, beberapa musisi memilih untuk melakukan perjalanan spritual ke India.

Hal tersebut akhirnya berdampak pada bagaimana mereka mempelakukan Tuhan mereka sebelumnya. Tuhan mereka akhirnya berdiri sejajar dengan dewa-dewa agama di India.

Lagu Symphony No. 9 tidak berhenti sampai disitu saja. Kubrick kembali menunjukkan penegasan nihilisme pada karakter Alex dengan menunjukkan fantasi kebebasan setelah mendengarkan lagu tersebut.

Terdapat empat adegan dalam montage fantasi Alex. Pertama adalah seorang wanita memakai gaun putih yang dihukum gantun, lalu tanah meledak, kereta yang meledak dan manusia jaman batu yang terancam nyawanya karena hujan batu. Ada satu adegan yang ditampilkan sebagai selingan diantara adegan-adegan tersebut, Alex menjadi drakula.

Kesemua adegan itu memiliki pemaknaan lambang yang sama yaitu kehancuran. Hal ini memunculkan kembali indeks yang menyatakan bahwa dalam keadaan mendengarkan lagu Symphony No. 9 Alex akan mengalami fantasi terhadap kekerasan. Alex pun menyatakan dalam narasinya bahwa fantasinya tersebut dinyatakan sebagai kumpulan gambar yang indah.

Penggunaan lagu Symphony No. 9 tidak selamanya memperlihatkan bagaimana hal itu memperlihatkan nihilisme yang ada dalam Alex. Hal itu juga terjadi di penghujung film ketika Alex berinteraksi dengan Menteri Dalam Negeri, 
Frederick. Frederick berusaha melakukan berbagai cara untuk menyelamatkan partainya dengan cara menggunakan Alex sebagai bonekanya.

Dalam adegan Alex dan Frederick berfoto bersama. Peneliti menemukan adanya sebuah pesan dari Kubrick bahwa ketika seorang elit politik di depan media bersama seorang rakyat maka tidak selamanya yang terlihat adalah benar. Sehingga disini muncul simbol yang terlihat dari gesture keduanya. Alex dengan acungan jempol dan Frederick dengan senyumnya. Interaksi keduanya memiliki kesatuan motif, kekuatan.

Iringan lagu Symphony No. 9 di dalam adegan ini merupakan movement yang terakhir sehingga terdengar begitu menghentak. Movement terakhir dari lagu ini memberi kesan bangkit dari keterpurukan. Hal ini bisa diperlihatkan dari Alex yang mengalami keterpurukan dan akhirnya mengalami kejayaan setelah ia kembali bisa memikirkan hal-hal yang berbau erotis.

Fantasi terakhir Alex di film ini adalah ia bercinta dengan seorang perempuan di tengah padang salju dan ditonton oleh orang-orang berpakaian bangsawan. Dalam adegan tersebut terdapat dua perlambangan yaitu ikon dan simbol. Ikon bisa dilihat dari gaya berpakaian yang dikenakan oleh para penonton Alex.

Secara heuritik pakaian yang mereka kenakan adalah pakaian di jaman Inggris kuno. Secara hermeneutik mempunyai makna bahwa mereka adalah bangsawan yang bertepuk tangan melihat kekuatan yang ditunjukkan oleh Alex.

Secara simbol bisa dilihat dari Alex bersama perempuan tersebut. Secara heuritik diperlihatkan mereka sedang bercinta di padang salju. Secara hermeneutik Alex menunjukkan dirinya sebagai lelaki perkasa yang mampu bertahan di dataran salju yang begitu dingin. Dan tentu saja Alex kembali merasakan kebebasan.

Hal ini juga merujuk pada aspek nihilistik yang ingin disampaikan oleh Kubrick. Bagi Alex, ia merasa sembuh bukan karena terapi Ludovico yang memaksa ia untuk patuh dan tidak bisa bertindak semaunya, ia justru merasa sembuh setelah tahu ia kembali bebas melakukan apapun. 


\section{Simpulan}

Dari hasil analisis tentang tanda dalam film

A Clockwork Orange dapat disimpulkan sebagai berikut. Tanda-tanda yang berkaitan dengan nihilisme di dalam film memiliki kaitan dengan lagu Symphony No.

9. Sehingga peneliti menemukan tandatanda tersebut ketika film menampakkan adegan yang diiringi lagu tersebut.

Lagu tersebut memicu Alex untuk bertindak kekerasan sekaligus sebagai simbol kebebasan dia. Karena itu lah Lagu Symphony No. 9 menjadi penanda utama dalm film ACO.

Hal itu diperlihatkan ketika Alex mendengarkan seorang wanita bernyanyi salah satu bait di Symphony No. 9. Keadaan kamar Alex yang juga memiliki tanda-tanda yang peneliti temukan ada kaitannya dengan intensi dari Kubrick, pembuat film tersebut. Fantasi yang diciptakan Alex ketika mendengarkan lagu tersebut.

Dan terakhir bagaimana lagu tersebut mengisyaratkan kebebasan dia kembali setelah ia merasa terkekang sebelumnya.

Peneliti juga menemukan bahwa Kubrick dalam memberikan tanda melalui lagu-lagu Symphony No. 9 berkaitan erat dengan apa yang terjadi di Inggris pada jaman 60an hingga 70an. Selain Nihilisme juga adanya budaya tandingan yang turut mendukung adanya gerakan nihilisme secara implisit.

\section{Daftar Pustaka}

Brink, David Owen. (1989). Moral Realism and the Foundations of Ethics. New York: Cambridge University Press.

Chandler, Daniel. (2007). Semiotics: the Basics. Taylor \& Francis e-Library.

Cobley, Paul dan Litza Jansz. (1999). Introducing Semiotics. Australia: Allen \& Unwin Pty. Ltd.

Ehrat, Johannes. (2005). Cinema and Semiotic: Peirce and Film Aestethics, Narration, and Representation. Canada: University of Toronto Press.

Kubrick, Stanley. (Produser/Sutradara). (1972). A Clockwork Orange. Inggris: Hawk Films. 136 Mins.

Mackie, John Leslie. (1977). Ethics: Inventing Right and Wrong. New York: Penguin Books.

Ratna, Nyoman Kutha. (2015). Teori, Metode dan Teknik Penelitian Sastra. Yogyakarta: Pustaka Pelajar.

Stam, R, Burgoyne, $\mathrm{R}$ dan LewisFlitterman, S. (2005). New Vocabularies in Film Semiotics: 
Structuralism, Post-structuralism and Beyond. Abingdon: Taylor \& Francis e-Library.

Wardoyo, Subur. (2005). Semiotika dan Struktur Narasi. Di Kajian Sastra, vol. 29,No. 1, Januari 2005.
Zaimar, Okke Kusuma Sumantri. (2014). Semiotika dalam Analisis Karya Sastra. Depok: PT. Komodo Books 